\title{
Empowerment of diversity in the Nepalese corporate sector
}

\section{Authors \\ Pragya Budhathoki: \\ Envisions acquiring \\ up-to-date business \\ knowledge and practical \\ skill competence to \\ transform organizational \\ performance and image. \\ budhathokipragya@ \\ gmail.com}

Bipana Sapkota:

Aspiring professional in the banking and

financial sector.

Raj Maharjan: Aims to promote entrepreneurial initiatives embedded with good governance in the field of corporate sector.

Shrijana Bista: Business graduate having an ambition to work as a responsible lead manager.

Aakash Gosain: Aims to serve as a specialist for sustainable business development and integrated business management.

\section{Key Words}

Corporate governance, gender empowerment, diversity, social inclusion; youth empowerment.

\begin{abstract}
Background: There are numerous policy developments undergoing addressing the issue of gender empowerment and social inclusion (GESI) in the corporate sector with an aim to socio-economic mainstreaming of the backward groups but the government programs and the national youth policy may still be lacking the effective implementation for addressing the needs, rights and aspirations of the overall backward people. The present researchers perceived strong need for closer assessment of effectiveness of the policy framework to promote diversity, especially in the corporate sector.

For this, the paper, as a whole, discusses within the broader framework of equality and inclusivity, the theme of women in corporate governance with particular reference to Nepalese corporate sector.
\end{abstract}

Objectives: This study was aimed to explore the present scenario of empowerment of diversity in the Nepalese corporate sector.

Methods: Fully based on desk research crafted on qualitative paradigms of study. Secondary data were used to collect the information on the issues, trends, matters relating to Gender equality and social inclusion (GESI) and youth empowerment.

Results: Effective compliance of corporate governance (CG) has played the significant role in promoting GESI and youth empowerment in the Nepalese corporate sector under changing context of the country and beyond.

Conclusions:As a result of multi-dimensional transformation of national structural system, there has been increasing sensitivity and application of GESI sensitive planning and implementation in the Nepalese corporate sector. Such a practice would serve instrumental in empowering women, youth and other marginalized sections of the society.

Implications: GESI compliance and youth empowerment in corporate and other service sectors should be made a part of national strategic direction at all levels of institutional governance and disciplining.

Paper type: Review paper 


\section{Introduction}

Gender equality and social inclusion (GESI) is the concept that addresses unequal power relation between women and men and between social groups that focuses on the need for action to rebalance these power relations, equal rights and respect for all individuals (Bagale, 2016). GESI refers to the cultural and socially constructed between the sexes. Gender is not about something we are born with, and not about something we have, but it is about something we do (West \& Zimmerman, 1987; as cited in Bagale, 2016) and something we perform (Butler, 1990; as cited in Bagale, 2016). It is an approach focused on delivering equal rights, opportunities, and mainstream services to all citizens rather than welfare to the needy. The approach also recognizes formal and informal institutions and, embedded in these institutions, power relations that disempower women, the poor, the vulnerable and the excluded groups (International Development Partners Group, Nepal, [IDPG], 2017). IDPG (2017) has stated that gender equality and social inclusion (GESI) are intended to address the misbalance on the power relation experienced by the people on the grounds of language, gender, wealth, location, wealth or the combination of all these dimensions and focuses on the need for action to rebalance these power relations, reduce disparities and ensure equal rights, opportunities and respect for all individuals regardless of their social identity.

Gender equality refers to the equal rights, resources, responsibilities and access to opportunities to all sexes. It implies that the interests, needs and priorities of different groups of men and women are taken into consideration, recognizing the diversity between them. It further considers people's right to develop their abilities and make choices without considering any limitations set by the strict gender roles (Ministry of physical infrastructure and transport [MOPIT], 2017). Wadesango (2011) has stated that when both sexes are able to share equally in the distribution of power and influence then there occurs equality between them. Gender equality encompasses gender equity, which refers to fairness of treatment for women and men, according to their respective needs. This may include equal treatment or treatment that is different, but which is considered equivalent in terms of rights, benefits, obligations, accountabilities and opportunities (Mainaly, Kafle, Thapa \& Joshi, 2018). Asian Development Bank (ADB), (2010) has stated that gender refers to the socially constructed roles and identities of men and women as well as the relationship between them. It has been further mentioned that the amended Civil Service Act 2007 reserves 45 percent of excluded groups in vacant post divided into 33 percent of women, 27 percent of ethnic groups, 22 percent of Madhesis, 9 percent of Dalits, 5 percent of differently abled, 4 percent of backward regions for increasing the effectiveness and responsiveness for the civil service. As stated MOPIT (2017) gender not only refers to male and female but also includes transgender or third gender categories because gender identity is one's innermost concept of self as male, female, a blend of both or neither. One's gender identity can be the same or different from their sex assigned at birth.

Likewise, social inclusion is understood as the removal of institutional barriers and the enhancement of incentives to increase the access of excluded individuals and groups to development and welfare opportunities. It is the process of outreach to include all sectors of so- 
ciety in planning and decision-making that affects their lives. GESI mainstreaming highlights the effect of programs, policies, and resource allocations on men and women, and different castes and ethnicities. Mainstreaming includes organizational transformation in administrative, financial, and organizational procedures, and in projects and programs. If GESI mainstreaming is done effectively, the mainstream will reflect an environment much closer to true democracy (Rural Reconstruction Nepal [RRN], 2013). Social inclusion is the strategy for addressing the inequality and socio-cultural discrimination and acts as an integral component for ensuring equality in the segments like education, representation in political and economic decision making processes, health care and decent work for women and disadvantaged groups (National planning commission [NPC] \& United Nations [UN] country team, 2018).

Election Commission Nepal (2016), on Gender and inclusion strategy 2015-2020, has labeled gender inclusion (GI) as a concept that addresses unequal power relations between women and men and between different social groups. It focuses on the need for actions to balance these power relations and ensure equal rights, opportunities and respect for all individuals regardless of their social identity. Gender and inclusion (GI) audit analyzes the following: 1. how an organization integrates/includes women and marginalized groups in its internal structures and programming/ projects; 2. identifies aspects of an organization which promote or hinder: gender equality; women's empowerment; ethnic diversity; the meaningful participation of all castes; the inclusion of persons with disabilities; and a welcoming workplace atmosphere; 3. recommends ways to strengthen promotion of GI mainstreaming in policies, programs and structures; and 4. engages in a long term process of organizational learning on GI mainstreaming.

This assessment uses the term social inclusion to refer to both the outcome and the process of improving the terms on which people are engaged in meaningful participation in society. The World Bank has defined social inclusion as the process of improving the terms for individuals and groups to take part in society. Another more advanced definition of social inclusion is the process of improving the ability, opportunity and dignity of people, disadvantaged on the basis of their identity, to take part in society. Social inclusion aims to empower poor and marginalized people. (Mainaly, Kafle, Thapa \& Joshi, 2018).

Sex refers to the natural and biological differences between male and female, so it is biological and is difficult to change, but gender is a social construct and gender roles depend upon the society and culture (Bagale, 2016). Walker and Walker (1997, as cited Bagale, 2016) have defined social exclusion as "Dynamic process of being shutout, partially or fully, from any of the social, economic, political, or cultural systems, which determine the social integration of a person in society" (p. 25).

ADB (2010) has investigated the status of social inclusion and gender equality in international, non-governmental, bilateral and multilateral organizations of Nepal. It was found that the employee composition of these organizations was represented by 54.2 percent Brahman and Chhetris, followed by 23.7 percent Newars, 18.3 percent Janajatis and 3.8 percent Dalits. It implies that there is an overrepresentation of Brahman and Chhetris and an underrepresentation of Dalits and Janajatis in these organizations. 
IDPG (2014) has investigated the status of gender equality and social inclusion in five districts of Nepal covering different geographic regions. A total number of 365 people belonging to different ethnicities and religious groups were selected as the sample for the study. The findings of the study indicated that in the year 2014, women representation was only 10.6percent in the civil service sector. The UN has defined youth as the person between the age group of 15-24. But the National Youth Council (NYC) Act, 2072 of Nepal prescribed the people between the age group 16- 40 years as youth and accounts for 40 percent of country population. According to the Housing Census Report (2011) 40 percent of the Nepalese population are under age group 16-40 years and considered as youth where 46 percent are men and more that 54 percent are women.

Youth has been defined as the people belonging to ages of 15-24 according to The United Nations. Whereas, in the context of Nepal, people belonging to the age group 16 to 40 are considered to be youth by (United Nations Development Programme [UNDP], 2018) on Nepal Youth Strategy 2018-2022. According to the census of June 22, 2011, the population of Nepal was $26,494,504$ with the youth (age 16 to 40 years) comprising about 41 percent. In recent times, concepts such as 'youth participation', 'youth bulge', 'youth employment', and 'youth empowerment' have been steadily gaining prominence in the international development discourse, similar to other priorities such as gender, protection, child rights, environment, and HIV/AIDS. In line with these international trends, youth has now emerged as a separate area of attention and concern in Nepal (Agrawal et al., 2014). As stated in MOPIT (2017) empowerment refers to gaining control over oneself through setting own priorities, gaining skills, solving problems, building self-confidence and developing self-reliance by enhancing the assets and capabilities of individuals and groups to function and to engage, influence and hold accountable the institutions that affect them.

Youth hold the potential to contribute in a variety of constructive roles within society, and ensuring youth's societal participation enhances their capacity for, and encourages initiation of, meaningful engagement in sustainable development. Educating youth and incorporating their issues in poverty reduction also prepares them for creating sustainable livelihood. (National Youth Policy [NYP], 2010) the only document with an exclusive focus on youth with clearly delineated age limits, envisions to prepare capable, creative and competent youth with scientific and positive vision. The objective being the establishment of youth in leadership roles so they can render a meaningful contribution to the economic, social, political, and cultural spheres of the nation, while guaranteeing their basic rights and also taking into consideration the sensitiveness of the younger age through youth empowerment (Agrawal et al., 2014).

Although, the government of Nepal has formulated various plans and policies related to GESI, there is a strong lack of implementation. Due to this, women are lacking behind and youth are migrating abroad seeking job and education. Lack of women participation and social exclusion is prevalent at all organizational levels in Nepal (Asian Development Bank, 2018). As stated by (IDPG, 2017), in the year 2014, only 10.6percent women were in the civil service. Likewise, unemployment rates are higher for young people than as compared to the adult population. For the people aged between 15 to 29 years of age, the unemployment rate 
is 19.2 percent. In terms of employment ratio, women are far behind as compared to men with 33.4 percent and 42.8 percent respectively. Therefore we would like to examine the current status of GESI and youth empowerment in Nepalese corporate sector by assessing the overall scenario and determine the appropriate policies and plans that would help to improve the current scenario.

The primary objective of the present work was to analyze the empowerment of diversity in the Nepalese corporate sector. The study was mainly guided by the purpose to analyze the problems related with GESI and youth empowerment in Nepalese corporate sector. In terms of detailed observation, the specific aims of this research were to:

a. assess the overall scenario on youth empowerment,

b. determine the policy developments governing GESI and youth empowerment,

c. examine the status of GESI and youth empowerment, and

d. produce the expected of effective consideration on GESI and youth empowerment in Nepalese corporate sector.

The focus of review of literature was to explore the empowerment of diversity in terms of GESI and youth empowerment in the Nepalese corporate sector. GESI has become a recognized indicator for social development. In the changing socio-political context of Nepal, issues of GESI are pertinent for social transformation.

GESI refers to a societal state where women and men of all social groups enjoy the same status and have equal access to all resources and opportunities. It focuses on affirmative actions to create a level playing field between disadvantaged and advantaged women, men and groups based on socially defined identity and prevailing power relations. Increasing numbers of youth leave the country either in the hopes of studying abroad or for employment. Although migration in itself not new to Nepal, approximately half a million Nepal's (excluding those in India) currently work abroad. The remittances account for more than 20 percent of the GDP and thus can be seen as a huge contribution to the national economy. Although remittances have greatly assisted in bringing down the poverty line, its impact on national development is very limited (Agrawal et al., 2014).

This study has focused on issues, challenges and the current scenario of GESI and youth empowerment in Nepalese corporate sector. If GESI and youth empowerment is critically analyzed then following questions need to be considered.

a. How is the concept of corporate governance and general compliance applied in the Nepalese corporate sector?

b. What is the overall situation of policy development governing GESI and youth empowerment in the Nepalese corporate sector?

c. What are the outcomes of effective consideration on GESI and youth empowerment in the corporate sector?

This paper may have its significance in different respects and for instance:

a. For national and international professional societies, associations and knowledge community, it will serve as a referred source of information to identify gaps, design 
and implement a series of other studies with focus on effective corporate governance.

b. Corporate governance and private institutions would be benefitted from the sectorial assessment of Nepal's potential for socio-economic development by promoting effective GESI and youth empowerment.

c. It helps to extend assistance for inclusive constitutional and policy formulation and reform and affirmative action policies for women and socially excluded groups, including high-level policy dialogue and advocacy.

d. It helps in providing targeted interventions to support women and socially excluded groups and extending assistance to incorporate gender and social inclusion issues in national development plans and strategies.

The conceptual coverage of the present work includes two key dimensions of empowerment of diversity, GESI and youth empowerment. The present scenario of equality and inclusivity in the corporate sector with particular reference to Nepal have been covered in the study. The information for the study were collected through secondary sources including journals, articles and books using the college library, the websites as well as expert consultation.

\section{Definition of key terms}

Corporate governance is defined as the process and structure used to direct and manage the business and affairs of the company towards enhancing business prosperity and corporate accountability with the ultimate objective. It is a system of law, contracts, and social norms that govern the structure by which corporations make decision (Zabri, Ahmad \& Wah, 2016).

Gender equality is the state in which the access to rights and opportunities is not affected by gender. This implies that women and men have equal ease of economic participation and decision making without the fear of coercion and violence. Gender equality does not require that men and women be treated exactly alike, but rather involves an absence of bias or discrimination (UNICEF, 2011).

Social inclusion can be understood as the entire process of improving the abilities, opportunities and dignity of people, disadvantaged on the basis of their identity, to improve their participation and position in the society (ADB, 2018).

The attitudinal, structural and cultural process whereby young people gain the ability and authority to act on their own terms rather than at the direction of others, implement change in their own lives and the lives of other people is defined as youth empowerment (Mecha, 2017).

\section{Concept and significance of corporate governance}

Governance simply refers to the process or act of governing and when it comes to an organized corporate sector, it is the way by which an organization is directed or controlled (Sigdel \& Koirala, 2015). Broadly defining, corporate governance deals with the customs, policies, laws and institutions that guide organizations and corporations in the way they act, administer and control their operations (Khan, 2011). It works to achieve the goal of the organization and manages 
the relationship among the stakeholders including the board of directors and the shareholders. Corporate governance serves and guides to secure the dedication of stakeholders with the objective to functionalize their skills, knowledge and experience to avail the full benefits. To achieve this, corporate governance sets legal terms and condition for the allotment of property rights among stakeholders, organizing their associations and manipulating their incentives for increasing their eagerness to work together. Further, corporate governance is vital because of the delegation of responsibility for production, process improvement and innovation (Suzanne et al., 2006; as cited in Sigdel \& Koirala, 2015).

Corporate governance basically explains the ways how a corporate firm is managed, controlled and directed. It is set of rules and indicatives which specifies how the management of a company is directed and controlled so as to maximize profit and value of the company. It specifies how the rights and duties are being distributed among the several stakeholders of the firm. All these are essentially aimed at improving board independence, transparency and accountability to the company's shareholders and other stakeholders and its effectiveness in fulfilling both its performance and functions (Andres \& Vallelado, 2008; as cited in Gnawali, 2018).

The issue of corporate governance arises from the agency theory that clearly defines that ownership of a corporate body is separated from its management and control (Berle \& Means, 1932; as cited in Adhikari, 2014). A corporate governance framework should protect shareholders' right, such as voting right, right to elect board member, right to get relevant information, interact and communicate with the management, equitable treatment of all shareholders (Tricker, 1984; as cited in Adhikari, 2014). Though Martin and Cullen (2006, as cited in Lamichhane, 2015) have argued that none of the theoretical perspective could fully summarize the complicities of an organization, Corporate Governance mechanisms like Board Characteristics, Audit Committee characteristics, Ownership Structures, are considered the measure for Corporate Governance variables (Poudel \& Hovey, 2013; as cited in Lamichhane, 2015).

Agrawal and Knoeber (1996; as cited in Gnawali, 2018) have defined corporate governance as a system, which has dual mechanism to control organizations; it can be external mechanism and internal mechanism. The internal mechanisms are concerned with the size and composition of the board of directors and external mechanisms are concerned with the influence of stockholder, the functioning of the markets for corporate control (Chen \& Lee, 2008; as cited in Gnawali, 2018). Outsiders define the external mechanism like shareholding policy and outside block holding etc. Firm's decision makers (top management) decide the internal mechanisms like size of board, remunerations and other internal policies. Whenever people get close to each other to comprehend the societal and organizational need they must have direction and control.

In the context of banking sector of developing countries, corporate governance is important for several reasons. First, banks have a dominant role in developing economies as they are important engines of economic growth. Second, banks in developing economies are typically the most important source of finance for the majority of firms. Third, banks in developing countries are usually the main depositories for the economy's savings. Fourth, many 
developing economies have recently liberalized their banking systems through privatization/ disinvestments and reducing the role of economic regulation. Consequently, managers of banks in these economies have obtained greater freedom in how they run their banks (Arun \& Turner, 2004; as cited in Adhikari, 2014). Studies have also shown that good corporate governance practices have led to significant increases in economic value added of firms, higher productivity, and lower risk of systemic financial failures for countries (The World Bank, 2005; as cited in Sigdel \& Koirala, 2015).

It is widely believed that good corporate governance is an important factor in improving the value of a firm in developing and developed markets. For a developing country like Nepal, Corporate Governance plays a significant role to attract Foreign Direct Investment and Foreign Portfolio Management, mobilize capital market saving and development outcomes (Sapkota, 2008; as cited in Lamichhane, 2015; ADB, 2010). The firms in developing countries can also reduce their agency costs through implementation of good corporate governance practices (Arora \& Sharma, 2016). Since corporate governance has a direct influence on its ability to attract low cost capital, efficiency with which a firm operates, its ability to meet expectations of society and the overall performance, the quality of corporate governance is important (Mohamad, 2004). However, the relationship between CG and the financial performance of a firm differs in developing and developed financial markets due to disparate CG structures in these markets resulting from dissimilar social, economic and regulatory condition in these countries. Before looking at the relationship between corporate governance and firm's performance, it is useful to have a framework with which to understand how corporate governance can affect firm behavior and economic performance. One of the problems with the current debate on CG is that there are many different, and often conflicting, views on nature and affect firm behavior and economic performance (Gnawali, 2018).

\section{Challenges in implementation of corporate governance prac- tices in Nepal}

Corporate governance is an underpinning factor for the proper operation of the institutions as a whole and are required for the ensuring the financial stability and building social credibility which ultimately leads to the long term sustainability of an organization. One of the major prospect of corporate governance is promoting the local empowerment by providing equitable opportunities for local people to govern the institution. The implementation of corporate governance enhance the use of local resources through the development of entrepreneurship and locally available skills and resources and support on the economic development of the people at local level. In other part, the best application of the corporate governance in the organization both at the private and government institutions will signify for the effective implementation of the governing rules, regulations, regulatory frameworks, acts and policies. Such best practices can act as a major tool for attracting more and more foreign direct investment (FDI) and multinational companies. Institutions seek for the support from the government and protection from the political and environmental factors. Nepal being established as the Federal country, organizations get opportunities for federalizing the corporation through the establishment of headquarters in different provinces and regions. 
Besides the significance of the implication of good corporate governance practices, there also exist several challenges in implementing them in the context of Nepal. One of the major challenges is the difficulty in coping with dynamic macro-economic factors. Nepal is a multi-ethnic country due to which the population is divided into different caste, ethnicity, race and gender and may create socio cultural differences while working under the same roof. At present the attitude of people towards an organization is changing. Though private institutions are established with profit motive, society has imposed corporate social responsibility among organizations. Such activities have demotivated organizations from restraining away from good corporate governance practices. Likewise, the existing corruption in the bureaucratic system has also been acting as a major challenge in successfully implementing corporate governance practices. The culture of late work, corruption, refusal from taking responsibilities by government employees act as barriers in implementing good corporate governance practices. Such type of environment develops personal vested interest among people in power and increases nepotism and favoritism. Due to such poor corporate governance practices, issues related to corporate unionism and division among groups has increased resulting in the decrease in organizational efficiency and degrading working environment.

\section{Policy developments governing GESI and youth empower- ment in the Nepalese corporate sector}

Nepal is signatory to International human rights instruments, 23 human rights bargains with legitimate structure in Nepal to a great extent supporting GESI, including the Convention on the elimination of all forms of discrimination against women (CEDAW), the Beijing platform for action (BPFA), the Child rights convention, the Convention on the rights of person with disabilities, the Sustainable development goals (SDGs), and UN Security Council resolutions 1325 and 1820. Nepal was the first nation in Asia to build up a National Action Plan (NAP) on women, peace and security in 2011 (Ministry of Women, Children and Social Welfare [MOWCSW] \& UN Women, 2017) on GESI Profile for Humanitarian Action and Disaster Risk Reduction, 2017.

Nepal's laws, constitution, and civil code contain a number of provisions that discriminate on the basis of gender, caste, ethnicity, and religion, including the provisions that formalize the caste system. In 1963 and 1990 there were some changes made to address these issues, but the constitution continued to include discriminatory provisions, particularly in relation to citizenship and nationality, inheritance, ownership, marriage and family, employment, and education. Significant changes have been made in recent years as a result of the changed political environment and extensive policy dialogue between the government, civil society organizations, and development partners (ADB, 2010).

Government of Nepal (2007; as cited in ADB, 2010) includes provisions that support gender equality and social inclusion and also it sets forth the right to equality and to rights against untouchability, racial discrimination, and exploitation (e.g., forced labor). According to article 13, it states to implement measures for the "protection, empowerment and advancement of women, Dalits, indigenous nationalities, and Madhesis". In 2007, the government took sev- 
eral policy actions to increase the representation of women and excluded groups in political institutions and the civil service. Constituent Assembly Member Election Act allocates seats to women, Dalits, ethnic groups, Madhesis, and the differently abled among others for the 240 electoral seats under the proportional electoral system. Similarly, the 2007 amendment to the Civil Service Act reserves 45percent of vacant posts for excluded groups, allocated as follows: women 33percent, ethnic groups 27percent, Madhesis 22percent, Dalits 9percent, differently abled 5percent, and backward regions 4percent to increase the effectiveness and responsiveness of the civil service (ADB, 2010).

Similarly, Government of Nepal (2007 - 2010; as cited in ADB, 2015), approved in 2007, dwelt extensively on social exclusion and was focused on 'inclusive development'. It identified as its long-term vision contributing to the broader national goal of achieving social inclusion and gender mainstreaming through increased participation of population of all class, caste and gender in the development, promotion and utilization of alternative energy sources (NPC, 2010; as cited in ADB, 2015) and has a separate section on social inclusion and gender mainstreaming. This is reinforced by 33 percent women representation, a proportional representation of Janajati, Dalits, Madhesi and Muslim population in the CA (Constituent Assembly)/Parliament and strengthened NGO involvement. The Three Year Plan also identified that alternative energy will contribute to employment generation and inclusive development but its objectives, policies, working policies and programs have not specified how inclusion will be addressed. In its long-term vision, it has directed that alternative energy promotion, contributing to rural development, enhancing rural economy and quality of rural life, increasing the employment opportunities and contributing to the sustainability of environment are the long term objectives (SNV, 2012; as cited in ADB, 2015).

Likewise, Government of Nepal (2010-2013; as cited in ADB, 2015) further emphasized that for peace building it is essential to address disparities in terms of caste, ethnicity, gender or region. It also identified that alternative energy will contribute to employment generation and inclusive development (NPC, 2010; as cited in ADB, 2015) but its objectives, working policies and program have not specified how inclusion will be addressed.

Further, the Government of Nepal (2013/2014-2015/2016; as cited in ADB, 2015), focuses on activities for economic and social transformation putting necessary regulations, laws, regulations in place; identifying necessary activities, ensuring participation of gender and the socially excluded in different government system. The paper speaks on securing and reserving their rights and also speaks explicitly of 33 percent representation in the governance system and 25 percent gender responsive budget allocation.

Various constitutional and legal provisions have strong GESI mandates inbuilt. The 2015 constitution states that there shall be gender equality, proportional inclusion, participation and social justice, (Part 4, Section 50[1]). Following this trend, the approach paper for the 14th Three-Year Development Plan (2016/17-2018/19) seeks to address structural problems in the economy such as inequitable access to productive means and resources to ensure sustainable development and shared prosperity (NPC, 2016). 
The government has enacted several laws like the Gender equality law (Act to Amend Some Nepal Acts for Maintaining Gender Equality, 2006) and the Good Governance Act, 2008, and amended the Civil Service Act, 1993 to promote non-discrimination, equity, and inclusiveness while also guaranteeing human rights and promoting local participation in development. Likewise, the government has developed GESI guidelines for some sectors, including the nationwide local governance and community development program, prepared the National plan of action for controlling gender-based violence and promoting gender empowerment, 2012, introduced Gender-responsive budgeting (GRB), mandated women's participation in the planning and execution of local development activities, and carried out GESI analysis and GESI audits of several sectorial ministries' programs (NPC, 2016).

Besides these broad policies that guide GESI issues in the country, acts and regulations cover the energy sector in Nepal, some of which with a stronger focus on GESI issues and others with clear deficits on these fronts (NPC, 2016).

Until recently, GESI policies and guidelines have been issued and implemented by seven major sectoral ministries namely, Agriculture, Education, Federal Affairs and Local Development, Forest, Health, Sanitation, Urban Development and Water Supply in Nepal. Many of these agencies have also established dedicated units with systems and trained staff to monitor the results. The major focus of these sectoral GESI strategies and guidelines is participation of Dalits, Madhesis, Adibasi/ Janajatis, women and people with disabilities in the formulation, implementation, monitoring and evaluation of sectoral policies, plans and programs. (IDPG, 2017).

Table 1 depicts the institutional mechanisms and structures created by Government of Nepal in order to address GESI issues in various levels:

Table 1: Government of Nepal (GoN) institutional mechanisms for GESI

\begin{tabular}{|c|l|}
\hline \multicolumn{1}{|c|}{ Central } & $\begin{array}{l}\text { National Planning Commission; Ministry of Women, Children and /Social Welfare } \\
\text { (MOWCSW) and its Department of Women Development; Ministry of Federal Affairs } \\
\text { and Local Development (MOFALD) and its Dalit and Adibasi/Janajati co-ordination } \\
\text { committees; constitutionally established National Commissions for Women, Dalits, } \\
\text { Indigenous Nationalities, Madhesis, Muslims, Tharus and a National Inclusion } \\
\text { Commission that is mandated to protect the rights of Khas Aryas, Pichardiaka } \\
\text { ("backward") class, persons with disabilities, senior citizens, laborers, peasants, } \\
\text { minority and marginalized communities, people of the Karnali, and the indigent } \\
\text { class; Gender/GESI Focal Points in NPC, MOFALD, MOWCSW and the ministries of } \\
\text { Education, Health, Urban Development, Forestry and Agriculture. }\end{array}$ \\
\hline District & $\begin{array}{l}\text { Women and Children Offices (WCOs), Social Committee with a Social Development } \\
\text { Officer of District Development Committees (DDCs); Adibasi/Janajati District } \\
\text { Co-ordination Committee and Dalit Class Upliftment District Co-ordination } \\
\text { Committee, the Gender Mainstreaming Co-ordination Committee (GMCC), and the } \\
\text { GESI Implementation Committee. }\end{array}$ \\
\hline VDC/Municipality & $\begin{array}{l}\text { Representative Integrated Planning Committee in each VDC; Ward Citizens' Fora } \\
\text { and Citizen Awareness Centres. }\end{array}$ \\
\hline
\end{tabular}

Source: Ministry of Urban Development. (2013). Gender equality and social inclusion operational guidelines of Ministry of Urban Development. 
Table 1 indicates the different institutional mechanism for GESI formulated and implemented by the Government of Nepal at different levels namely, central, district and VDC/ municipality level. With an objective to achieve gender equality and social inclusion, co-ordination committees aimed towards strengthening the position of minorities and excluded groups have been formed at all three levels. In addition to these excluded groups, equal consideration was given to protect the rights of senior citizens, laborers, peasants and the differently-abled people. Likewise, offices dedicated towards uplifting the position of minorities and creating public awareness were formed in co-ordination with District Development Committees and Village Development Committees.

In addition to these institutional mechanisms, GRB has been introduced by the Government of Nepal since the fiscal year 2007/2008. The major objective behind this is to ensure that government attention and accountability is diverted in the area of GESI for improving the condition of gender equality and social inclusion of people in the country. Likewise, the development in this area is monitored as part of the regular annual budgeting process. In order to measure the gender responsiveness of projects, it should meet five criteria, 1 . Women's participation in decision making roles and program planning, 2. Their capacity building, 3. Benefit sharing by them, 4 . Women's increased access to employment and income-earning opportunities and 5. Reduction in women's workload.

On the basis of meeting this criteria, projects are identified as directly responsive and indirectly responsive. The total budget allocated under GRB from 2007/08 to 2017/18 is illustrated below;

Table 2: Gender responsive budget

\begin{tabular}{|c|c|c|c|c|c|c|c|}
\multirow{2}{*}{ SN } & \multirow{2}{*}{ FY } & \multicolumn{2}{|c|}{$\begin{array}{c}\text { Directly Responsive } \\
\text { Amount (in } \\
\text { billions) }\end{array}$} & Percent & $\begin{array}{c}\text { Amount (in } \\
\text { billions) }\end{array}$ & percent & \multicolumn{2}{c|}{$\begin{array}{c}\text { Amount (in } \\
\text { billions) }\end{array}$} & percent \\
\hline 1 & $2007 / 08$ & 19.09 & 11.30 & 56.03 & 33.16 & 93.87 & 55.54 \\
\hline 2 & $2008 / 09$ & 32.91 & 13.94 & 83.58 & 35.41 & 119.53 & 50.64 \\
\hline 3 & $2009 / 10$ & 49.46 & 17.30 & 104.16 & 36.43 & 132.32 & 46.27 \\
\hline 4 & $2010 / 11$ & 60.61 & 17.94 & 112.65 & 36.30 & 154.64 & 45.76 \\
\hline 5 & $2011 / 12$ & 73.33 & 19.05 & 176.21 & 45.78 & 135.35 & 35.17 \\
\hline 6 & $2012 / 13$ & 87.07 & 21.51 & 178.63 & 44.13 & 139.11 & 34.36 \\
\hline 7 & $2013 / 14$ & 112.05 & 21.75 & 227.30 & 43.94 & 177.4 & 34.31 \\
\hline 8 & $2014 / 15$ & 135.56 & 21.93 & 278.38 & 45.04 & 204.15 & 33.03 \\
\hline 9 & $2015 / 16$ & 182.51 & 22.27 & 393.16 & 47.98 & 243.79 & 29.75 \\
\hline 10 & $2016 / 17$ & 242.30 & 23.10 & 508.20 & 48.45 & 298.41 & 28.45 \\
\hline
\end{tabular}

Source: Ministry of Finance (MoF). (2017). Gender responsive budget.

Table 2 illustrates the total budget allocated for gender responsive projects (directly as well as indirectly responsive) from the fiscal year 2007/08 to 2016/17. The budget allocation show an increasing trend as the budget allocated for projects directly responsive to gender has more than doubled to 23.10 percent in 2016 from 11.30 percent in 2007. In relation to 
indirectly responsive projects, the budget allocation shows a fluctuation over the years, the lowest being 56.03 billion in the year 2007/08 and the highest at 508.20 billion in the year 2016/17 (MoF, 2017).

\section{Sustainable development goals}

SDG 5 discusses on achieving the gender equality and empowerment of all women and girls rights. The major aim of this goal is to end all forms of discrimination that are prevailing at the different parts, eliminating all forms of violence against women and girls in the public and private peripheral, ensuring the equal participation of women in leadership and decision making on all levels of decision making in political, economic affairs and the rights regarding the women empowerment. In the Fourteenth plan, Nepal targeted of achieving 7.2 annual growth rate in year (2073/74-2075/2076 [2017-2020]), where country has developed the five priority development strategies which are closely linked with the Sustainable development goal. SDG 5 explains on the gender equality, (SDG 1-6, 7, 8, 9, 10, 16) explain on social inclusion, (SDG 1-6) explain on social development and social security Ministry of Physical Infrastructure and Transport (2017). The table below explain on the target and indicators on the gender equality and women equality.

Table 3: Sustainable development goals

\begin{tabular}{|c|c|c|c|}
\hline SDG & Target and Indicators & 2015 & 2030 \\
\hline $5 \cdot 1.1 .1$ & $\begin{array}{l}\text { Wage equality for similar work (ration of women's wage } \\
\text { to that } \\
\text { of men) }\end{array}$ & .62 & .92 \\
\hline $5 \cdot 1.1 .2$ & Gender Inequality Index & .49 & .05 \\
\hline $5 \cdot 4 \cdot 1$ & Ratio of women to men in labor force & .93 & 1 \\
\hline $5 \cdot 1.1 .3$ & Gender Empowerment Measurement (Index) & .57 & .69 \\
\hline $5 \cdot 5 \cdot 1 . a$ & $\begin{array}{l}\text { Proportion of seat held by women in national parliament } \\
\text { (in percent) }\end{array}$ & 29.5 percent & 40 percent \\
\hline 5.5.1.b & $\begin{array}{l}\text { Proportion of seat held by women in provincial } \\
\text { parliament (in percent) }\end{array}$ & 33 percent & 40 percent \\
\hline 5.5.1.c & $\begin{array}{l}\text { Proportion of seat held by women in local government } \\
\text { bodies (in percent) }\end{array}$ & 40.5 percent & 42 percent \\
\hline $5 \cdot 5 \cdot 2.1$ & $\begin{array}{l}\text { Women participation in decision making level in the } \\
\text { private sector (in percent) }\end{array}$ & 25 percent & 45 percent \\
\hline $5 \cdot 5 \cdot 2.2$ & Womens participation in cooperative sector (in percent) & 50 & 50 \\
\hline $5 \cdot 5.2 .4$ & $\begin{array}{l}\text { Ratio of women to men in professional and technical } \\
\text { sector }\end{array}$ & 24 & 40 \\
\hline
\end{tabular}

Source: National Planning Commission (NPC). (2016). Sustainable development goals.

The Constitution of Nepal, promulgated in 2015, promotes policies to encourage youth participation in the all-round development of the country. For this, it emphasizes the creation and provision of opportunities for young people in the fields of education, health and employment, aimed at boosting their personal development and empowerment. 
The Ministry of Youth and Sports (MoYS) was established in 2009 with the mandate of promoting and supporting youth development in Nepal. The ministry's core areas of work include developing youth policies, strategies and plans; creating implementation mechanisms; and ensuring resources are allocated to execute these policies and plans. It is also responsible for monitoring and evaluating the implementation of the National Youth Policy. It has launched several programs for youth welfare, such as the Local Youth Partnership Program 2009/2010. The MoF, meanwhile, allocates a portion of the annual budget to youth development activities, such as the Youth Self-Employment Program, the Grand Youth Sports Competition, and the Youth Mobilization Program, among others.

This ten-year strategy for youth development was prepared by the National Youth Council under the Ministry of Youth and Sports, and mainly focuses on areas of education, employment, health, social security, leadership development and sports and entertainment. It is to be implemented through the National Youth Council and its chapters at subnational levels.

The National Youth Policy was developed by the MoYS to empower young people. It aims to do this by building youth capacity to contribute to a prosperous, modern and just Nepal, and integrating young people in national development through meaningful participation and leadership. The policy was developed in the context of the Interim Constitution of Nepal 2007, which mandated that the state "shall pursue a special policy to mobilize youth human resources for the development of the country."

The Fourteenth Development Plan (2016/17-2018/19) includes a chapter on youth development, in which it recognizes the role of young people as major contributors to socio-economic development and sustainable peace, and the need to provide them opportunities to exercise their potential. This acknowledgement of youth in the government's plan represents an important step forward, a victory for the coalition of organizations advocating on behalf of Nepal's youth. According to the plan, the policies and program of the government for the fiscal year 2073-74 (2016-2017) have highlighted provisions targeted at youth. 50,000 young people, for instance, will be self-employed every year through the Youth self-employment program, which is to be scaled up. As part of this, unemployed youth will also be granted access to concessional loans on the basis of project ideas UNDP (2018) on Nepal Youth Strategy 2018-2022.

\section{GESI and youth empowerment status in Nepalese corporate sector}

As per the UN Human Development Report (2016), Nepal lies in 115th place out of 157 countries for registering the highest degree of inequality and territories in 2015. For supporting the gender equality and women's empowerment, GON has adopted a gender mainstreaming strategy. Nepal's Interim Constitution (2007 as cited in Asian Development Bank Report) has provided an interim legal framework for the government and has promoted for gender equality and social inclusion through inclusive state restructuring, ensuring fundamental rights to women and positively targeting to socially excluded groups. The current ThreeYear Interim Plan (2008-2010) have recognized the need to adopt an inclusive development process for ensuring the access and participation of excluded groups and has set quantitative targets to achieve the target set. 
In the formal economy, women's access to employment, especially in the service sector and as teachers in primary, lower secondary and secondary levels (37.5percent, 20.1percent and 13.1percent respectively) is found to have increased (NPC, 2014). According to National review of sustainable development goals (2017), Nepal has made impressive progress in promoting gender equality and women's empowerment. Gender parity is achieved in all levels of education. The ratio of girls to boys in primary education increased from 0.79 in 2000 to 1.09 in 2015. Gender parity was achieved in primary education in gross and net enrolment in 2015. The ratio of girls to boys in secondary education increased from 0.70 in 2000 to 1.0 in 2015. Gender parity was also achieved in secondary education. The ratio of women to men in tertiary education increased many fold from 0.28 women to every man in 2000 to 1.05 in 2015. Girls now perform better than boys in primary and secondary level education completion and retention in Grades 5 and 8. The main unfinished agendas are to increase the enrolment of women in technical and vocational education and training, address disparities in education outcomes and improve the quality of education. According to the International Finance Corporation, Nepalese women own 14,300 small and medium enterprises in the country and employ more than 200,000 individuals. So far, 22,500 women in the country have registered businesses with government agencies (ND, 2017).

In general, youth are regarded as agents of change. Even in Nepal we take youth as the pioneers of economic, social, political, and cultural transformation, and the backbone of the nation. They vitalize a stagnant situation; build networks, mutual support structures, and platforms for advocacy; and share resources and ideas. Youth also represent an asset upon which the future of any society depends; hence, it is important to ensure that needed interventions are created for youth's overall development. To do this, it is crucial to frame and establish the necessary policies for youth, especially in the areas of livelihood and employment. NYP (2014) of the MoYS, in its attempts to address some of these concerns, is a step in the right direction (Agrawal et al., 2014).

The Constitution of Nepal is a significant milestone for GESI and enshrines equal rights for women, the poor, the vulnerable and people from different social groups with positive provisions including affirmative action to address historical disadvantage and a ban on sex or caste/ethnicity-based discrimination. The article on Rights of Women establishes for women the right to equal lineage; right to safe motherhood and reproductive health; right to participate in all bodies of the State; right to property and family affairs; and positive discrimination in education, health, employment and social security. It also makes any act of violence against women punishable by law. The Right to Equality further elaborates the special provisions by law for the protection, empowerment or development of citizens, including those described by the constitution as "socially or culturally backward." The Right to Social Justice establishes the people's right to participate in state bodies on the basis of the principles of inclusion and proportional representation (IDPG, 2017).

In addition, lack of decent jobs, poor health, frequent armed conflicts, and fewer opportunities to participate in decision-making processes are hurdles that have contributed to the erosion of youth's abilities, and can be viewed as an impediment to their growth. Consequently, their 
engagement has not been meaningful in the country's social, political, and economic spheres. The lack of sufficient opportunities for youth carries psychological costs in society that are reflected in youth violence, delinquency, drug and alcohol abuse, and crime (Agrawal et al., 2014).

Female youth also expressed that they frequently face discrimination in the workplace and thus have a difficult time securing a job. Even when female youth are able to secure jobs, they are often unable to receive the same opportunities within their jobs as their male counterparts. Furthermore, societal and cultural norms dictate that women should not be out in the evenings, making it challenging for female youth to work the long hours that their male colleagues do. Their inability to work late often creates an additional "reason" employers can use to discriminate against young women in the workplace (Agrawal et al., 2014).

Youth in Nepal have been affected by the country's conflicts in various ways. Many young people have been victimized, suffered direct violence, lost education and vocational opportunities, or have been displaced. Many combatants, as well as youth associated with the armed forces (e.g. porters, sex slaves, and others within the armed forces that are not combat- ants) are reported to be facing difficulty in returning to formal education. Although a few NGOs and government initiatives have introduced rehabilitation programs such as free adult education, vocational training, and seed money for initial investments to help former combatants, few youth have actually benefited from these programs (Agrawal et al., 2014). From the review of the economic survey, 2017/18 following activities were carried out for improving the social inclusion and youth empowerment:

There has been developed the provision to provide a maximum of Rs. 200 thousand without any collateral through Youth and Small Entrepreneurship Self-employment Programs targeting the un-employed youth from the age group 18 to 50 years. It was reported that 44841 youth have become self-employed with the provision to provide loan.

In the FY 2016/17, it is reported that 240 youth were involved in rural youth entrepreneurship and 500 youths have participated in Youth Skill and Leadership Development Program through National Youth Council. 212 youths participated in internal youth experience exchange program only 212 youths participate and 250 youths participated in the program of material support for the differently able youth.

For bringing forward the Dalit community, there was provided higher education scholarships to 600 people, employment training to 300 people, facilitation of public service preparation classes to 300 people and income skill oriented training to 150 people in the fiscal year 2016-17.

For the upliftment of Indigenous People and Chepang Development, the living standard reform was conducted for 19 times and scholarship was granted to 1000 people while 4331 people were trained in the institutional capacity development programs in fiscal year 2016/17.

\section{Outcomes of effective GESI and youth empowerment consid- erations in the corporate sector}

According to UNDP gender empowerment, women are active in public and economic life, indicates that women's participation and representation remain lower than that of men in the 
political, economic, and professional domains, although there has been an increase in the proportion of economically active women, their earned income is about one-third that of men and women continue to have low access to property ownership, financial credit, and political power (UNDP, 2009). The gender equality in work not only benefits the men and women in work but also to the business through providing businesses to recruit and retain the best employees, increasing productivity and competitiveness, best use of the human resources of an organization, marinating the public image as well as enhances creativity and innovation which are critical success factors for an organization (Warth, 2009).

Caste, ethnicity, and regional identity and geographical location are also strong determinants of poverty and unequal development outcomes. Poverty monitoring by the Central Bureau of Statistics shows that poverty remains high in the mid-western and far-western regions, and that poverty rates are higher in rural areas (35percent) than in urban areas (10percent). The advantaged groups experienced greater declines in poverty (with current rates among Newars of 14percent and Brahman and Chhetri of 18percent) than socially excluded groups (with current rates among Dalits of 46percent, Muslims 41percent, hill Janajati 44percent, and Terai Janajati 35percent). There are unequal outcomes for women in different groups and regions, which indicates by other social development. The interaction between gender and other factors of exclusion is evident in literacy rates. Dalit women from the Terai belt have the lowest literacy rate at 17percent, compared to the national female average of 55percent and male average of 81percent. The gender gap in literacy is highest among the Madhesi other caste groups, with men three times as likely to be literate as women 72percent versus 24percent (ADB, 2010).

Differences among groups are also evident in that the HDI is higher in urban than rural areas (0.630 versus 0.482), in the central region compared to the mid-west (0.531 versus 0.452), and among Brahman and Chhetri (0.552) compared to Dalits (o.424) and Muslims (0.401), where it also show that Brahmans and Newars generally do better than the Dalits, Adivasi Janajatis, Madhesi other castes, and Muslims on health indicators, including antenatal care, total fertility rates, and early childhood mortality. The government, development partners, international and national NGOs, and civil society has undertaken policy and institutional reforms in various sectors to promote increased and more equitable development outcomes. This section considers gender and social exclusion by sector, together with current institutional capacity and approaches to addressing the challenges identified (ADB, 2010).

In Nepal's Constitution of 1990, women were prevented from transmitting citizenship to their children. This changed through the Nepal Citizenship Act (2006), which allows children to claim citizenship in their mother's name. Due to the patriarchal and patrilineal system, women in Nepal had been denied access to and control over familial property. The legal framework maintained this discrimination until the 11th Amendment of the Civil Code 2002, which repealed several discriminatory provisions of the Civil Code along with other acts and entitled women to significant rights. However, while the 2007 Interim Constitution provided equal inheritance rights to sons and daughters, this only applies while the daughters remain unmarried (ADB, 2010). 
In addition, a Women and Children Service Center (WCSC) has been established at the central police headquarters and in several districts with the objective of investigating crimes against women and children, including sexual offenses, human trafficking, child marriage, polygamy, and domestic violence. As of 2007, there were 25 WCSCs across Nepal. There are also efforts to increase the representation of women and other excluded groups through the police: amendments to the Police Regulation and to the Armed Police Regulation (2007) provide for reservations for recruitment as follows: 32percent Adivasi Janajatis, 28percent Madhesis, 15percent Dalits, 20percent women, and 5percent from backward regions (ADB, 2018).

The Gender Equality Act (2006) brought tangible changes in laws related to sexual violence against women. A major achievement of this act is the provision that an offender convicted for rape must compensate the victim for mental and physical damage. Also important is the 2009 Domestic Violence (Crime and Punishment) Act, which for the first time recognizes domestic violence as a crime punishable by law. However, while the act recognizes domestic violence as a crime, it contains provisions for negotiations through police offices, which seems contradictory (ADB, 2015).

\section{Best practices of gender equality and social inclusion}

Procter and Gamble Company: It is an American multinational consumer goods corporation with the amalgamation of people from over 145 nationalities. It upholds the strong values of diversity within its own organization and have planned the various activities for promoting the diversity and equality. For promoting the diversity and equality, P \& G created a short film focused on "the talk" in which many black Americans with their kids talked about the racial bias in order to protect, prepare and encourage them. Since its launch in 2017, film has generated intense dialogue on social media and millions of online views. With the intention of reducing the difficulty of people with visual impairments to differentiate shampoo from hair conditioner while in the shower, P \& G decided to start the "visual impairment aid" through raising indentations on every bottle. For dispelling the workplace myth related with women, P \& G with joint collaboration of Seneca women presented a though- provoking interactive exhibit, "women at work: Myth vs. Reality" to bust false gender notions that become hurdles to women's advancement in the workplace. For fueling girls aspirations in education and value girl's education as much as a boy, it created TV shows that will explore gender equity issues in child relevant ways. P\& G have committed for spending $\$ 100$ million with women owned business outside of the U.S. over a three year period for prioritizing women's economic empowerment.

Unilever: Unilever is a British-Dutch transnational consumer goods company co-headquartered in London, United Kingdom, and Rotterdam, Netherlands. Its products include food and beverages (about 40 per cent of its revenue), cleaning agents, beauty products, and personal care products. It believes that becoming a truly diverse and inclusive company is not only the right thing to do but is a crucial in helping to grow business, attract and retain talent, and engage the people who buy the products. For empowering the women, it is building the foundation by collaborating with other business and organizations to create opportunities for women across the extended supply chain, in the sales and customer development operations 
and via products and brands for 2.5 billion consumers worldwide where $70 \%$ are women. Unilever consisted of $50.7 \%$ of women in management position in the UK and Ireland which was only $41.8 \%$ in 2010 . Unilever have the gender focused diversity and inclusivity and addressed through following for focusing on getting women into top management:

a. Globally women control nearly $\$ 12$ trillion share of the overall $\$ 18.4$ trillion global consumer spending.

b. Women will be our future work force because the majority of university graduates in developed countries are women. According to the OECD (2010), this is projected to rise from $57 \%$ in 2005 to $63 \%$ in 2025 .

c. Organizations working on the established principles that more diversity of thought leads to greater innovation and business growth.

\section{Summary of findings}

With globally increasing concern over GESI and youth empowerment, plans, policies and system practices targeted towards improving the condition of socially excluded groups like women, ethnic groups, dalits, madhesis, muslims, people in the backward regions and differently abled are being developed. In relation to this, several policies have been formulated for increasing gender equality and social inclusion situation in corporate sector which will help in achieving increased access of women and socially excluded groups in different initiatives and missions of socio-economic development.

Various international development agencies and partners working in Nepal missions are undertaking gender empowerment and social inclusion (GESI) as one of the cross-cutting themes of institutional operations and project management. In this respect, both professional and institutional system capacity development with GESI sensitivity has been emphasized.

Nepal was the first country in Asia to develop a national action plan (NAP) on women, peace and security in the year 2011. It carried out consultations with the women affected by violence and inequality in 52 out of 75 districts covering all five development regions. This made Nepal's NAP, the most consulted NAP globally. The objective behind this development was to support women empowerment, as a special interest of global concern.

The amendment to Civil Service Act, 1993 has also supported social inclusion by making a provision to fill 45 percent of vacant posts on inclusive basis and the remaining 55 percent through open competition. This 45 percent is again converted to 100 percent which is allocated as follows; 33 percent to women, 27 percent to ethnic groups, 22 percent to madhesi, 9 percent to dalits, 5 percent to differently abled and 4 percent to backward regions.

Seven sectoral ministries of Nepal namely, agriculture, education, federal affairs and local development, forest, health and sanitation, urban development and water supply have issued and implemented GESI policies and guidelines for improving the level of truthful participation of excluded groups. 
In addition to this, the government of Nepal has formulated institutional mechanisms and structures in order to address GESI issues in three levels -- central, district and municipal level. A number of committees have been formed at these levels to address the issues and uplift the position of excluded groups and regions.

GESI compliance was further supported by policy makers through the introduction of GRB in the fiscal year 2007/o8. Projects were categorized as directly gender responsive and indirectly gender responsive on meeting certain criteria and allocated budget by the government. Data shows that budget allocated by the government has increased from 19.04 billion in the fiscal year 2007/o8 to 242.30 billion in 2016/17. This indicates that over the time, introduction of the number of gender responsive projects has been increasing with positive response and ownership of the government.

Furthermore, NPC has included gender equality as one of the core goals SDGs. Under this, the commission targets to improve the condition of gender equality in the country through increasing the ration of wage equality, gender empowerment measurement index, proportion of seats held by women in national parliament, provincial parliament, local government bodies and women's participation in decision making in the private sector. Whereas, it targets to reduce the gender inequality ratio from 0.49 in the year 2015 to 0.05 by 2030.

\section{Recommendations for Policy Implication}

On the basis of overall study and learning insights gathered through the present study, the present researchers would like to recommend for following policy and action implications at different levels to address the issues and challenges facing GESI compliance and youth empowerment in Nepalese corporate sector:

a. Corporate governance practices, GESI compliance and youth empowerment in corporate and other service sectors should be made a part of national strategic direction at all levels of governments and corporate regulation as well as disciplining. For this, all levels of governments should act swiftly for timely amendment of policy regulations.

b. Education sector must emphasize GESI in the academic courses for providing knowledge to students about the prevailing situation and importance of it in the national development. It will empower students on identifying the gender differences and social exclusion that are prevailing in community and carry out steps for reducing it.

c. Youth organizations and local clubs should get coordinated with politically active youth, political parties and nonprofit organizations for implementation of the plans and policies developed at national level so that the activities developed reach upon the targeted groups. Working under such collaboration creates synergy among the organizations working with the similar objective.

d. Information on the rights and privileges provided to socially excluded people must be advertised using the sources of communication like radio, television, internet and newspapers. 
e. The GESI Coordinator should spearhead the strategic leadership and provide technical guidance on GESI perspectives in and across the program components, ensuring that GESI is mainstreamed into field and policy activities.

f. Youth organizations need to be proactive and inquire about their rights and responsibilities with the local government institutions to establish two-way communication and coordination between the groups.

g. The government programs and the NYP will help in addressing the needs, rights and aspirations of migrant youth workers and helps in decreasing the size of $\mathrm{Ne}-$ pal's migrant youth population and also help in making plans and establish programs with assurance of consistency and prioritization in term of allocation of budget, monitoring and evaluation, effective from F/Y 2075/o76.

\section{Conclusions}

This paper has provided with basic insights on position of gender equality, social inclusion and policy developments for maintaining gender equality and social inclusion in Nepal. Also, the paper has attempted to assess the prevailing inequality on the basis of caste, ethnicity, gender and the advantaged and disadvantaged groups.

Before preparing this paper, the members of work team bore little knowledge and concern in this particular issue, but this experiential learning broadened the horizon of learning and sensitivity towards GESI related issues in the society and corporate governance.

However, various policy formulations in relation to GESI and youth empowerment indicate the increasing concern of government towards the need for inclusiveness in different sectors of the nation, Nepal still has a long journey to make in this particular domain of national development to achieve shared happiness.

This is well reflected through various policies and development initiatives undertaken by the governments at all three levels -- federal, provincial and local - so as to promote gender equality, social inclusion and empowerment.

In addition, budget allocation for gender responsive projects have been increasing in the recent years. This trend indicates increasing concern and actions for improving the level of empowerment of women, socially excluded groups and youths by increasing their role in various sectors of national development with a vision to achieve prosperity.

\section{References}

Adhikari, P. (2014). Corporate governance practices in commercial banks in Nepal. Abhinav International Monthly Refereed Journal of Research in Management \& Technology, 3 (9), pp. 55-56. Available at: https://abhinavjournal.com/journal/index.php/ISSN-2320-oo73/article/viewFile/416/ pdf_109. Retrieved on: February 14, 2019.

Agrawal, K., Dahal, S., Rawal, N., Koirala, S., Pant, A., Adhikari, S., \& Tsuchida, D. (2014). Youth and public policy in Nepal. Kathmandu: Youth Policy Press. Available at: http://www.youthpolicy.org/ pdfs/Youth_Public_Policy_Nepal_En.pdf. Retrieved on: February 9, 2019.

Arora, A., \& Sharma, C. (2016). Corporate governance and firm performance in developing countries: evidence from India. Corporate Governance, 16(2), pp. 420-436. Available at: https://www. 
researchgate.net/publication/298790284_Corporate_Governance_and_Firm_Performance_ in_Developing_Countries_Evidence_from_India. Retrieved on: May 8, 2019.

Asian Development Bank. (2010). Overview of gender equality and social inclusion in Nepal, pp. 9-15. Available at: https://women-lead.org/team. Retrieved on: February 11, 2019.

Asian Development Bank. (2015). Gender review of national energy policies and programmes in Nepal, p.12. Available at: https://www.energia.org/cm2/wp-content/uploads/2016/o5/Gender-Review-NEPAL.pdf. Retrieved on: February 11, 2019.

Asian Development Bank. (2018). Gender equality and social inclusion assessment of the energy sector, $p$. 19. Available at: https://thehimalayantimes.com/opinion/private-sector-governance-room-improvement/. Retrieved on: January 13, 2019.

Asian Development Bank. (2018). Overview of gender equality and social inclusion in Nepal, p. 4. Available at: https://women-lead.org/team. Retrieved on: January 13, 2019.

Bagale, S. (2016). Gender equality and social inclusion in technical and vocational education and training. Journal of Training and Development, 2, pp. 25-32. Available at: https://www.researchgate.net/ publication/306398948. Retrieved on: January 13, 2019.

Election Commission Nepal. (2016). Gender and inclusion strategy (2015-2020). Kathmandu. Available at: https:// ECN-Gender-Policy-And-Strategy-2016-en-v1percent2o (2).pdf. Retrieved on: February 10, 2019.

International Development Partners Group (2017). A common framework for gender equality and social inclusion, p. 1-6o. Available at: https://www.undp.org/content/dam/nepal/docs/generic/GESIpercent20frameworkpercent2oReport_Final_2017.pdf. Retrieved on: May 8, 2019.

Gnawali, A. (2018). Corporate governance and its impact on financial performance in Nepalese commercial banks. International Journal of Modern Research in Engineering and Management, 1, pp. 4151. Kathmandu. Available at: http://www.ijmrem.com/paper/vI_i7/IJMREM_Fo17041051.pdf. Retrieved on: February 12, 2019.

Kelles-Viitanen, A., \& Shrestha, A. (2012). Gender equality and social inclusion: promoting the rights of women and the excluded for sustained peace and inclusive development, p.1-57. Available at: http:// gate.unwomen.org/resources/docs/gendereqaulity/UNCT\%20Nepal_Gender\%20Equality\%20 and\%20Social\%2oInclusion_2011.pdf. Retrieved on: July 22, 2019.

Khan, H. (2011). A literature review of corporate governance. International Conference on E-business, Management and Economics, p. 25. Available at: http://www.ipedr.com/vol25/1-ICEME2011-A10015. pdf. Retrieved on: May 8, 2019.

Lamichhane, S., \& Li, L. (2002). Corporate governance and performance in commercial banks in Nepal. Bangkok: University of the Thai Chamber of Commerce. Available at: http://utcc2.utcc.ac.th/ utccijbe/_uploads/InProcess/201612/Corporate\%2ogovenance\%20and\%20Performance\%20 in\%20Commercial\%2oBanks\%20in\%20Nepal.pdf. Retrieved on: July 22, 2019.

Mainaly, R., Kafle, S., Thapa, S., \& Joshi, S. (2018). Promoting gender equality and social inclusion: Nepal's commitments and obligations. Kathmandu: INHURED International. Available at: https:// asiafoundation.org/wp-content/uploads/2018/10/Promoting-Gender-Equality-and-Social-Inclusion-Nepals-Commitments-and-Obligations.pdf. Retrieved on: February 8, 2019.

Mecha, N. (2017). The role of micro-finance on youth empowerment. An examination on theoretical literature. International Journal of Scientific and Research Publications, 7(2), p. 436. Available at: http:// www.ijsrp.org/research-paper-0217/ijsrp-p6259.pdf. Retrieved on: May 10, 2019.

Ministry of Finance. (2017). Gender responsive budget. Kathmandu: Government of Nepal. Available at: https://mof.gov.np/en/gender-responsive-budget-76.html. Retrieved on: May 10, 2019. 
Ministry of Physical Infrastructure and Transport. (2017). 2018-2022 United Nations development assistance framework for Nepal. Kathmandu: Government of Nepal. Available at: https://www.npc.gov.np/ images/category/UNDAF_2018-2022_with_signature_page.pdf. Retrieved on: May 17, 2019.

Ministry of Urban Development. (2013). Gender equality and social inclusion operational guidelines. Kathmandu. Government of Nepal. Available at: http://www.nepalpolicynet.com/new/wp-content/ uploads/2013/o9/GESI-Guidelines-en.pdf. Retrieved on: July 22, 2019.

Mohamad, S. (2004). The importance of effective corporate governance. SSRN Electronic Journal. Available at: https://www.researchgate.net/publication/228237979_The_Importance_of_Effective_Corporate_Governance. Retrieved on: July 22, 2019.

National Planning Commission (NPC). (2014). Nepal MDG progress report 2013. Kathmandu: Author. Available at: https://www.npc.gov.np/images/category/Nepal_MDG_2013.pdf. Retrieved on: May 9, 2019.

National Planning Commission (NPC). (2016). Three-year plan approach paper, 2016/17-2018/19. Kathmandu: Author. Available at: http://npc.gov.np/images/category/14_plan_approach_paper3. pdf. Retrieved on: February 14, 2019.

National Planning Commission (NPC). (2017). National review of sustainable development goals. Kathmandu: Author. Available at: https://sustainabledevelopment.un.org/content/documents/16513Nepal.pdf. Retrieved on: February 10, 2019.

Rural Reconstruction Nepal (RRN). (2013). Mainstreaming gender equality and social inclusion in community support program. Kathmandu: Community Support Program/UKaid. Available at: csp_gesi_ assessment.pdf. Retrieved on: February 12, 2019.

Sigdel, B. R., \& Koirala, S. (2015). Corporate governance in Nepalese financial sector: does policy matter? Lalitpur: Nepal Administrative Staff College. Available at: http://dms.nasc.org.np/sites/default/ files/documents/Corporatepercent2oGovernancepercent2oResearchpercent2oTrilochan.pdf. Retrieved on: February 14, 2019.

United Nations International Children and Education Fund (UNICEF). (2011). Promoting gender equality: an equity-focused approach to programming, p. 11. Kathmandu: Author. Available at: https:// www.unicef.org/gender/files/Overarching_Layout_Web.pdf. Retrieved on: May 10, 2019.

United Nations Development Program (UNDP). (2009). Nepal human development report 2009. State Transformation and Human Development, p. 38. Kathmandu: Author. Available at: http://hdr.undp.org/en/ reports/nationalreports/asiathepacific/nepal/name,19112,en.html. Retrieved on: February 10, 2019.

United Nations Development Program (UNDP). (2018). UNDP Nepal Youth Strategy, 2018-2022, p. 1-66. Kathmandu: Author. Available at: https://www.undp.org/content/dam/nepal/docs/2018_undpnepal/UNDP_NP-Youth-Strategy.pdf. Retrieved on: July 22, 2019.

United Nations Development Program (UNDP). (2016). Human development report 2016: Human development for everyone, p. 1-286. Available at: http://hdr.undp.org/sites/default/files/2016_human_ development_report.pdf. Retrieved on: July 22, 2019.

United Nations Women. (2017). Nepal gender equality and social inclusion profile for humanitarian action and disaster risk reduction, p.1-15. Available at; https://reliefweb.int/report/nepal/nepal-gender-equality-and-social-inclusion-gesi-profile-humanitarian-action-and. Retrieved on: May 9, 2019.

Zabri, S. M., Ahmad, K., \& Wah, K. K. (2016). Corporate governance practices and firm performance: Evidence from top 100 public listed companies in Malaysia. Procedia Economics and Finance, 35, pp. 287-296. Available at: http://sci-hub.tw/https://doi.org/10.1016/S2212-5671(16)ooo36-8. Retrieved on: May 10, 2019. 